\title{
DRASTIC METHOD AND CORRELATION WITH CHROMIUM LEVEL DUE TO TANNERY INDUSTRY IN RANIPET AREA GROUNDWATER VULNERABILITY ASSESSMENT, VELLORE DISTRICT, TAMILNADU, INDIA
}

\author{
AMBIGA, K. - ANNADURAI, R. \\ Department of Civil Engineering, SRM University \\ Chennai, Tamilnadu, India \\ (e-mail: ambigacivil.scsvmv@gmail.com; phone: +91-994-407-6844) \\ *Corresponding author \\ e-mail: annaduraisrm@yahoo.com; phone: +91-984-067-9948 \\ (Received $13^{\text {th }}$ Apr 2016; accepted $9^{\text {th }}$ Jan 2017)
}

\begin{abstract}
The main aim of this study is to evaluate the groundwater assessment and pollution by using the DRASTIC method and the correlation between the chromium strength present in and around Ranipet areas. The present study is to determine the vulnerable zone for groundwater pollution by integrating hydrogeological layers in GIS environment. Thirty five groundwater samples were collected from the study area and analyzed in the laboratory for physico-chemical parameters and heavy metals like chromium during 2012. DRASTIC means depth to water table, recharge rate, aquifer media, soil permeability, topography, the impact of the vadose zone, and hydraulic conductivity and this can be incorporated in the DRASTIC model using GIS techniques. In the model has vulnerability index value between 128-166 being high and value between 166-199 being very high whereas the chromium concentration between $0.035 \mathrm{mg} / \mathrm{l}$ to $0.5429 \mathrm{mg} / \mathrm{l}$. The statistical study puts into proof a great positive correlation between vulnerability and application of the chromium in the groundwater. High chromium awareness is present in high contamination areas over and above in moderate polluted areas. The present model can be used for estimation and groundwater management.
\end{abstract}

Keywords: GIS, parameters, pollutants, polluted areas, well water samples

\section{Introduction}

In any nation, groundwater is one of the most important natural resources, helping as a major source of water to residential communities, industries and agriculture purposes. The major source of groundwater has turned into the only water source since the limited availability of surface water (Mohammad et al., 2015). Hence, the prevention of groundwater contamination is essential for effective groundwater resource management and vulnerability assessment (Krogulec, 2013). The assessment of groundwater vulnerability to pollution has been subject to severe study during the past years and a variety of methods have been developed. The simplest to apply, the DRASTIC model includes D-depth of water, R-recharge, A-aquifer media, S-soil, T-topography, I-impact of vadose zone, C-conductivity (Tirkey, 2013). The final aim is the development of an integrated method which could successfully predict the specific vulnerability or the pollution risk under intense environmental stress. The pollution index has been used in this analysis that is the chromium concentration. The selection of this index was based not only on the fact that it constitutes the main contaminant that human activities introduce into the environment of the study area, but also it has been proposed as a representative indicator of groundwater quality degradation (Gupta, 2014). DRASTIC method is more economical and less time consuming to assess a wide range of regional 
groundwater vulnerability, overcoming sloppy, uncontrolled development of land, and undesirable activities (Mukherjee et al., 2016). This method was first developed for the US Environmental Protection Agency. Then the method has been modified by many researchers and scientists based on geological or hydro geological settings, climate conditions, and other special situations (Wang et al., 2012). Geographic Information System (GIS) is a very efficient tool for analyzing, interpreting, manipulating and incorporating the geological, hydrogeological and geomorphological data (Pradhan et al., 2013). The objective of the study area is to determinate the groundwater vulnerability using the DRASTIC method and the correlations that can be established between this and the chromium concentration level present in and around Ranipet.

\section{Materials}

The study region is sited in and around Ranipet area is about $154.52 \mathrm{Km}^{2}$ and having Latitude N 12 52'30' $-12^{\circ} 57^{\prime} 30^{\prime}$ ' and Longitude E 79 $15^{\prime} 00^{\prime \prime}-79^{\circ} 25^{\prime} 00^{\prime}$. The region mainly includes Ranipet, Walajapet, Arcot and Melvishram as shown in (Fig. 1). The water source of the study region is mostly Palar River and Ponnai River as shown in (Fig. 2). The Ranipet area is a persistent polluted area and exporting tanned leather. The many industries are processing leather in the area and discharging their effluents on the open land surrounding water bodies and into the lakes and river. Most of the parameters which indicate that the maximum permissible limit as per standards. The effluents were polluting the river, lakes and causing ecological matter and human health (Neshat, 2013). In the geological study region is having crystals of granite rocks as shown in (Fig. 3).

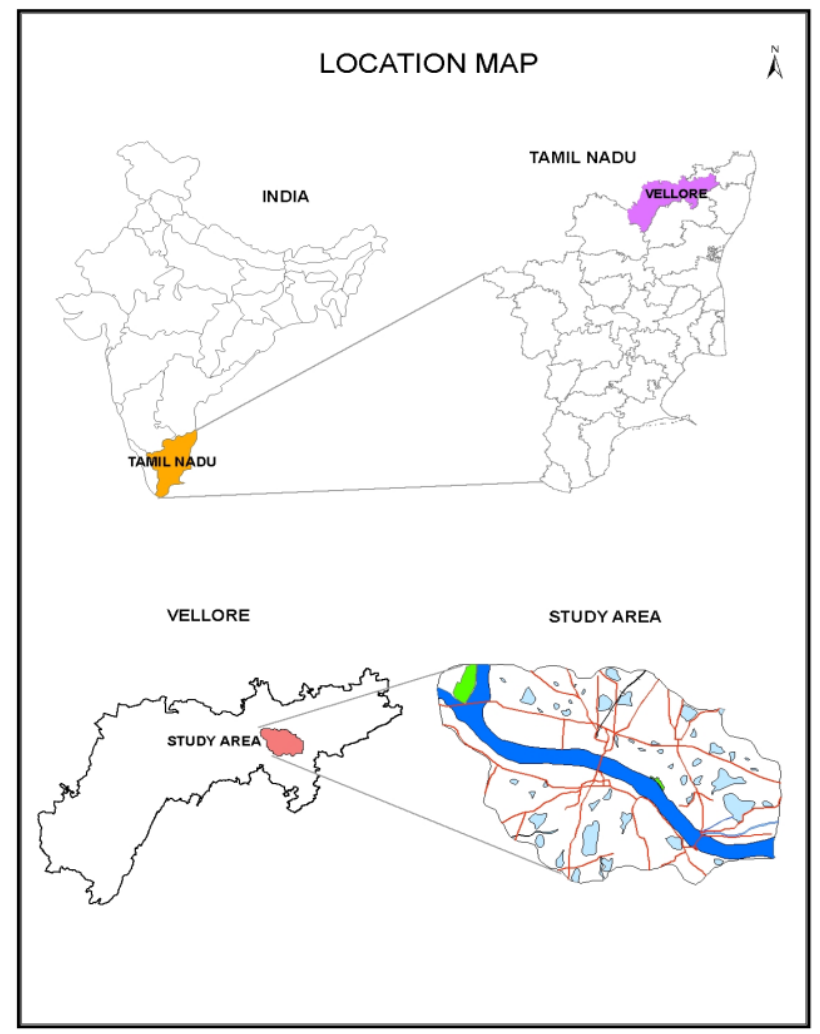

Figure 1. Location of the study area 


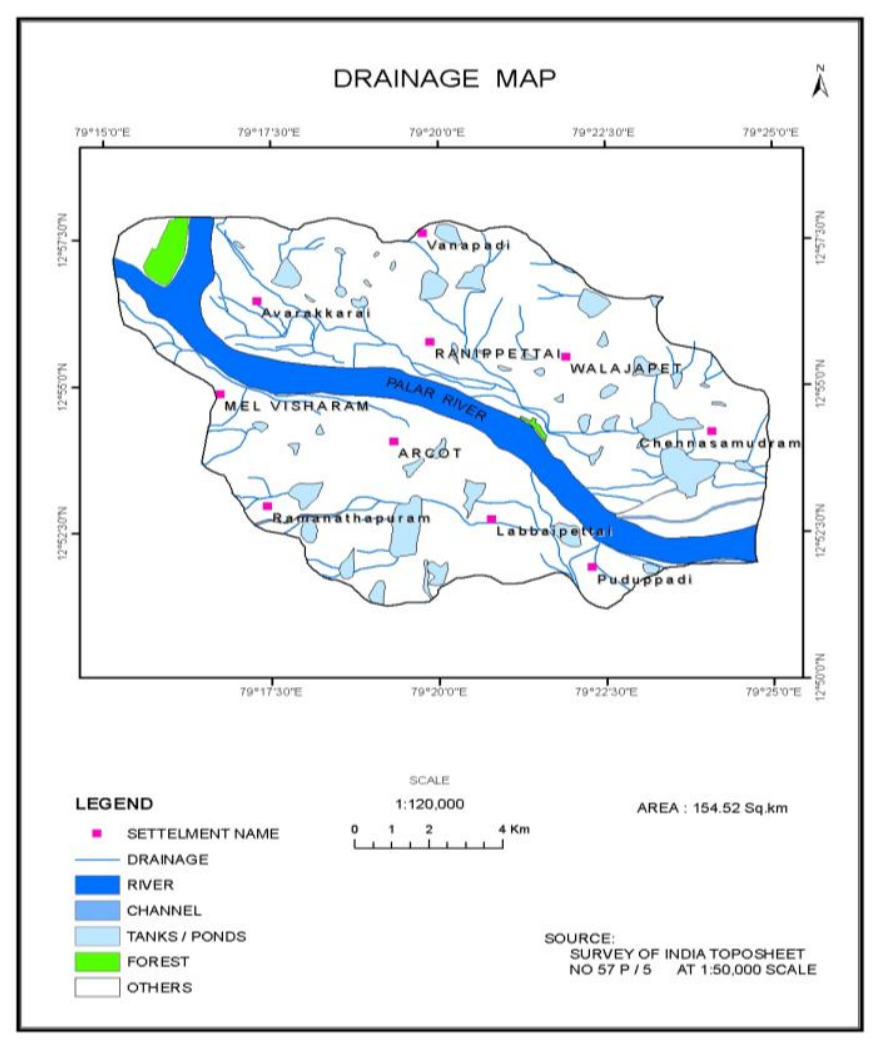

Figure 2. Drainage of the study area

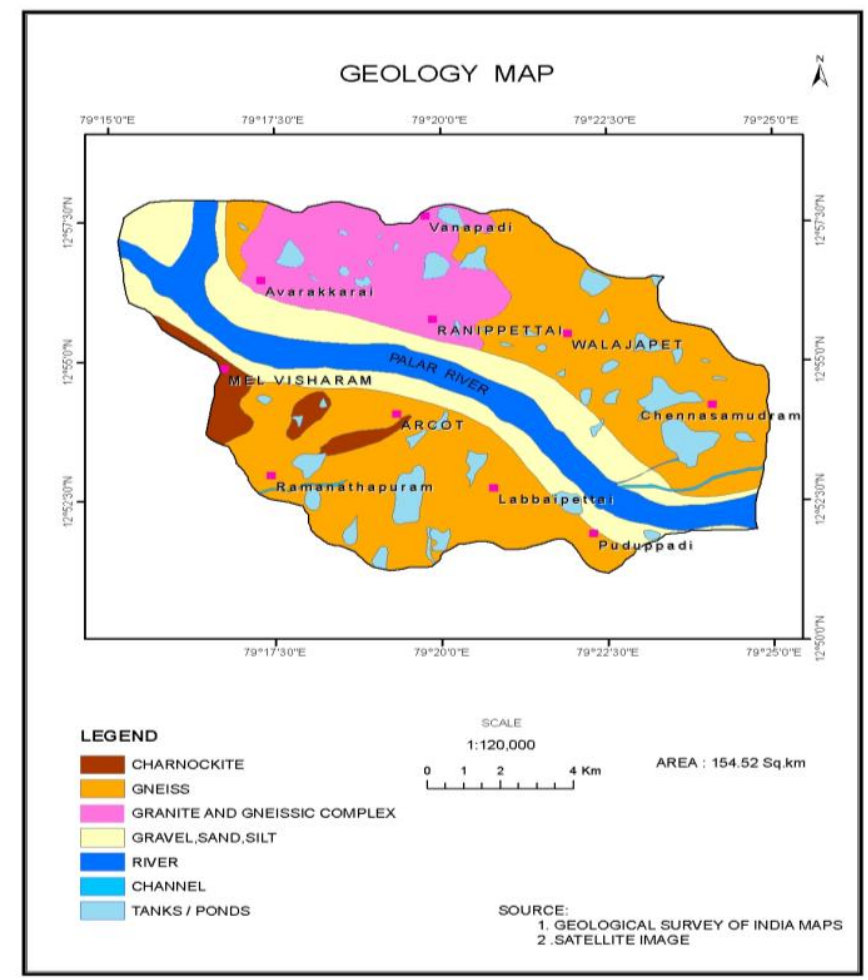

Figure 3. Geology of the study area 


\section{Methodology}

The water samples were collected from thirty five different open and tube wells during 2012 as shown in (Fig. 4) and were analyzed by physic-chemical parameters and heavy metal like chromium as per norms. Contamination is one of the highly health risks is the chromium which occurs in bore wells, open wells and industrial waste waters. Table 1 shows the chromium was analyzed by spectrophotometer. One of the most widely used models to assess wide range of potential contaminants is DRASTIC index (Bai, 2012). Methodology flowchart for groundwater vulnerability analysis using DRASTIC model in GIS as presented in the (Fig. 5). This method uses some hydrogeological factors of an area in order to determine the relative groundwater vulnerability to contaminants. DRASTIC includes seven classes - Depth to the groundwater (D), Recharge net (R), Aquifer media (A), Soil media (S), Topography (T), Impact of vadose zone (I) and Conductivity of the aquifer (C).

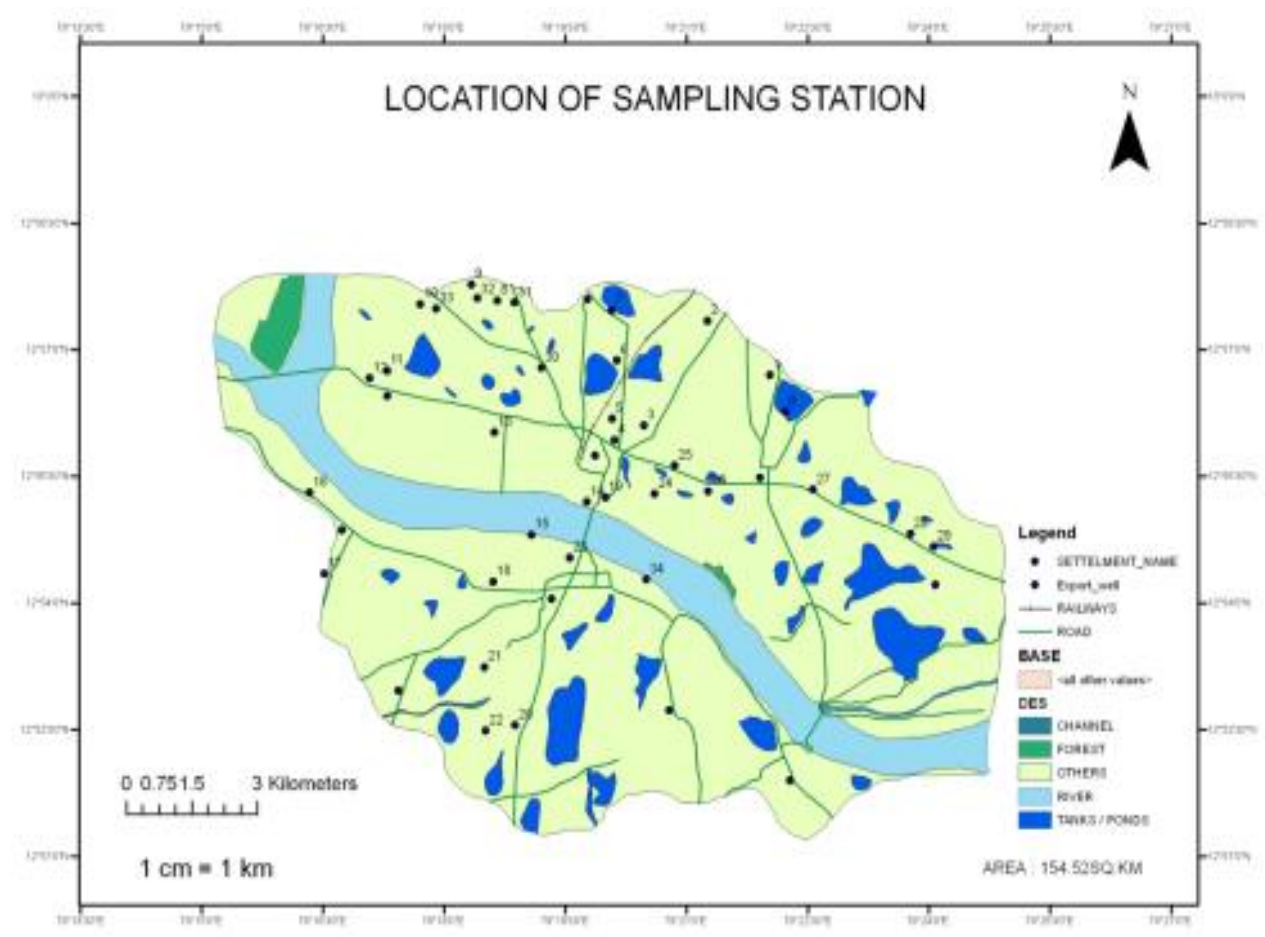

Figure 4. Location of the sampling station

These classes are then weighted and ranked, and then are combined to obtain a final ranking value using a groundwater vulnerability algorithm. There are three significant parts: weight, ranges and ratings (Mukherjee et al., 2016). Each DRASTIC classes has assigned a weight relative to each other in order of importance from 1 to 5 , the least significant is allocated one and five for the most significant. For each class have been ascertained ranges based on its impact on pollution potential. The ratings for each feature has been assigned a value between 1to 10, providing a relative assessment between ranges in each feature. To build and manage the database was used Microsoft access, meanwhile for spatial distribution and other GIS analysis was used ArcGIS map 10.1 (ESRI). 
Table 1. Analysis of chromium parameter during 2012

\begin{tabular}{|c|c|c|c|c|c|}
\hline Well No & $\begin{array}{c}\text { Well } \\
\text { Type }\end{array}$ & Chromium PPM & Well No & $\begin{array}{c}\text { Well } \\
\text { Type }\end{array}$ & $\begin{array}{c}\text { Chromium } \\
\text { PPM }\end{array}$ \\
\hline 1 & DW & 0.2452 & 19 & BW & 0.2452 \\
\hline 2 & BW & 0.1926 & 20 & BW & 0.3152 \\
\hline 3 & BW & 0.1401 & 21 & BW & 0.1751 \\
\hline 4 & BW & 0.1926 & 22 & DW & 0.1401 \\
\hline 5 & BW & 0.1926 & 23 & BW & 0.0876 \\
\hline 6 & BW & 0.2802 & 24 & BW & 0.0525 \\
\hline 7 & BW & 0.4904 & 25 & BW & 0.1226 \\
\hline 8 & DW & 0.4203 & 26 & BW & 0.1576 \\
\hline 9 & BW & 0.3678 & 27 & BW & 0.0350 \\
\hline 10 & BW & 0.3327 & 28 & BW & 0.1226 \\
\hline 11 & BW & 0.3152 & 29 & BW & 0.1051 \\
\hline 12 & BW & 0.2977 & 30 & BW & 0.1401 \\
\hline 13 & BW & 0.3152 & 31 & BW & 0.1226 \\
\hline 14 & BW & 0.3678 & 32 & BW & 0.1051 \\
\hline 15 & BW & 0.5429 & 33 & BW & 0.0701 \\
\hline 16 & BW & 0.4904 & 34 & BW & 0.1401 \\
\hline 17 & BW & 0.2802 & 35 & BW & 0.0350 \\
\hline 18 & BW & 0.2277 & \multicolumn{3}{|l}{} \\
\cline { 2 - 4 } & \multicolumn{3}{|l|}{}
\end{tabular}

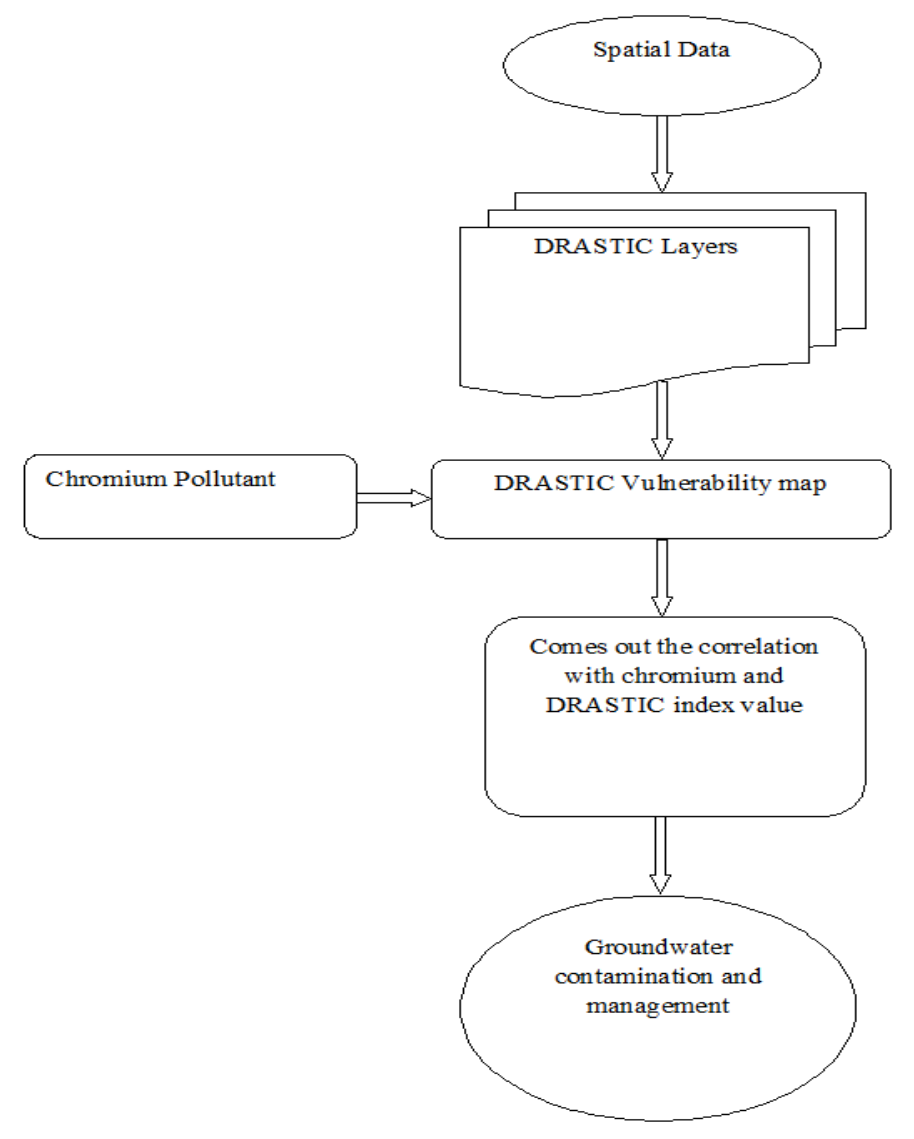

Figure 5. Flowchart for groundwater vulnerability analysis using the DRASTIC model in GIS 
The DRASTIC vulnerability map referred to a composite description of all the results from the intersection of thematic maps parameter and then combined by overlaying according to the index equation. In order to calibrate the DRASTIC model, chromium concentration was selected as the primary contamination parameter. Thirty five wells were selected for sampling and analyses were taken during 2012; the exact position of each well was determined using GPS techniques and measured by spectrophotometer.

According to the calculation of DRASTIC index equation:

$$
\mathrm{DI}=\left(\mathrm{D}_{\mathrm{r}} \mathrm{D}_{\mathrm{w}}\right)+\left(\mathrm{R}_{\mathrm{r}} \mathrm{R}_{\mathrm{w}}\right)+\left(\mathrm{A}_{\mathrm{r}} \mathrm{A}_{\mathrm{w}}\right)+\left(\mathrm{S}_{\mathrm{r}} \mathrm{S}_{\mathrm{w}}\right)+\left(\mathrm{T}_{\mathrm{r}} \mathrm{T}_{\mathrm{w}}\right)+\left(\mathrm{I}_{\mathrm{r}} \mathrm{I}_{\mathrm{w}}\right)+\left(\mathrm{C}_{\mathrm{r}} \mathrm{C}_{\mathrm{w}}\right)
$$

The highest weight of 5 has been assigned to two parameters. The depth to water and the impact of the vadose zones because, lower the water table higher will be the chance of pollutants to reach to ground water. These parameter ratings are used for all evaluations. Weights are assigned for various hydrological settings, which ranges from 1 to 5 , with higher weights representing greater pollution potential. These seven sets of data layers were digitized and were converted to raster data sets that were processed, (Eq.1).

The higher the DRASTIC index, the greater is the groundwater pollution potential. DRASTIC model rates relative sensitivity of land units by integrating information on $\mathrm{D}$, $\mathrm{R}, \mathrm{A}, \mathrm{S}, \mathrm{T}, \mathrm{I}$ and $\mathrm{C}$ classes in determining a ranking of groundwater sensitivity. It was designed to allow flexibility so that the local hydro-geological setting and its parameters could be weighted suitably (Mirhosseini et al., 2013). The hydro-geological setting is defined by the spatial representation of designated map able units. The map able units incorporate the major hydro geological factors, which affect and often control groundwater movement. Table 2 shows the modifications to the DRASTIC were incorporated in both the selection and weighting of these factors.

Table 2. Rating and weight of DRASTIC classes

\begin{tabular}{|c|c|c|c|}
\hline \multicolumn{4}{|l|}{ 1. Depth to water level (D) } \\
\hline Ranges & Ratings $\left(D_{\mathrm{r}}\right)$ & Weight $\left(D_{w}\right)$ & $\begin{array}{c}\text { Total } \\
\text { Weight }\end{array}$ \\
\hline $2.9-4.5$ & 9 & \multirow{2}{*}{5} & 45 \\
\hline $4.5-8.4$ & 7 & & 35 \\
\hline \multicolumn{4}{|l|}{ 2. Natural Recharge Rates $(\mathbf{R})$} \\
\hline Ranges & Ratings $\left(\mathrm{R}_{\mathrm{r}}\right)$ & Weight $\left(R_{w}\right)$ & $\begin{array}{c}\text { Total } \\
\text { Weight }\end{array}$ \\
\hline Built Up/Mining / Quary & 1 & \multirow{5}{*}{4} & 4 \\
\hline Open/vacant land / scrub land & 3 & & 12 \\
\hline Sandy area & 5 & & 20 \\
\hline Crop land / plantation/fallow land/forest & 6 & & 24 \\
\hline Waterbodies & 8 & & 32 \\
\hline \multicolumn{4}{|l|}{ 3. Aquifer Media (A) } \\
\hline Ranges & Ratings $\left(\mathrm{A}_{\mathrm{r}}\right)$ & Weight $\left(A_{w}\right)$ & $\begin{array}{c}\text { Total } \\
\text { Weight }\end{array}$ \\
\hline Charnockite/granite and gneissic complex & 3 & \multirow{3}{*}{3} & 9 \\
\hline Granite and gneissic complex/hornblende gneiss & 4 & & 12 \\
\hline Gravel,sand,silt & 8 & & 24 \\
\hline
\end{tabular}




\begin{tabular}{|c|c|c|c|}
\hline \multicolumn{3}{|l|}{ 4. Soil Media (S) } & \\
\hline Ranges & Ratings $\left(\mathrm{S}_{\mathrm{r}}\right)$ & Weight $\left(\mathrm{S}_{\mathrm{w}}\right)$ & $\begin{array}{c}\text { Total } \\
\text { Weight }\end{array}$ \\
\hline Tanks/Ponds/ Channel & 10 & \multirow{7}{*}{2} & 20 \\
\hline Sandy clayloam & 9 & & 18 \\
\hline Sandy clay & 8 & & 16 \\
\hline Loamy sand & 7 & & 14 \\
\hline Sandyloam & 6 & & 12 \\
\hline Clayloam & 3 & & 6 \\
\hline Clay & 1 & & 2 \\
\hline \multicolumn{3}{|l|}{ 5. Topography (T) } & \\
\hline Range & Ratings $\left(\mathrm{T}_{\mathrm{r}}\right)$ & Weight $\left(\mathrm{T}_{\mathrm{w}}\right)$ & $\begin{array}{c}\text { Total } \\
\text { Weight }\end{array}$ \\
\hline $0-2$ & 10 & \multirow{5}{*}{1} & 10 \\
\hline $2-6$ & 9 & & 9 \\
\hline $6-12$ & 5 & & 5 \\
\hline $12-18$ & 3 & & 3 \\
\hline$>18$ & 1 & & 1 \\
\hline \multicolumn{4}{|l|}{ 6. Vadose Zone Media type (V) } \\
\hline Range & Ratings $\left(\mathrm{I}_{\mathrm{r}}\right)$ & Weight $\left(\mathrm{I}_{\mathrm{w}}\right)$ & $\begin{array}{c}\text { Total } \\
\text { Weight }\end{array}$ \\
\hline Tanks/Ponds & 1 & 5 & 5 \\
\hline Clay & 3 & & 15 \\
\hline Sandyclay/Loamysand & 4 & & 20 \\
\hline Channel & 6 & & 30 \\
\hline ClayLoam & 7 & & 35 \\
\hline Sandyclayloam & 8 & & 40 \\
\hline Sandyclay & 9 & & 45 \\
\hline \multicolumn{4}{|l|}{ 7. Hydraulic conductivity (C) } \\
\hline Aquifer Type/Range & Ratings $\left(\mathrm{C}_{\mathrm{r}}\right)$ & Weight $\left(\mathrm{C}_{\mathrm{w}}\right)$ & $\begin{array}{c}\text { Total } \\
\text { Weight }\end{array}$ \\
\hline River/Tanks/Ponds & 0 & 3 & 0 \\
\hline Sandyclayloam/Clayloam/Sandyloam/Clay & 1 & & 3 \\
\hline
\end{tabular}

In general, the aquifer potential protection increases with depth to water table. The depth of the water table ranges from 2.9-8.4 m below ground level. The ratings were 9 and 7 as the ground water table is at a good height. The depth to water table map is given in the (Fig. 6).

The rainfall data have been taken from IMD, the data has been interpolated using the technique, Inverse Distance Weight (IDW) interpolation in the ArcGIS spatial analyst tool and it is classified as Built Up/Mining/Quarry Open/vacant land/scrub land Sandy area Cropland/plantation/fallow land/forest/water bodies. The map for the net recharge is given in the (Fig. 7).

The recharge rating value lies in the range of 1-8. The different soil materials are the most vulnerable to contamination and hence it was assigned the rating of 8 as the permeability is very high. The Charnockite/granite and gneissic complex is the least vulnerable due to impermeable nature and the rating is 3, Granite and gneissic complex/fissile hornblende gneiss, which are permeable rock units, have high permeability; therefore, these units were assigned with ratings of 4 . The map showing aquifer media is given in the (Fig. 8). 
It has significant impact on the movement of the amount of recharge water, which infiltrates deeper into the aquifer; hence it also affects the downward movement of the contaminants in the Vadose zone (Al-Rawabdeh et al., 2013). The rating assigned from 10 (soil-tanks/ponds/channels) to 1 (clay). The soil media is given in the (Fig. 9).

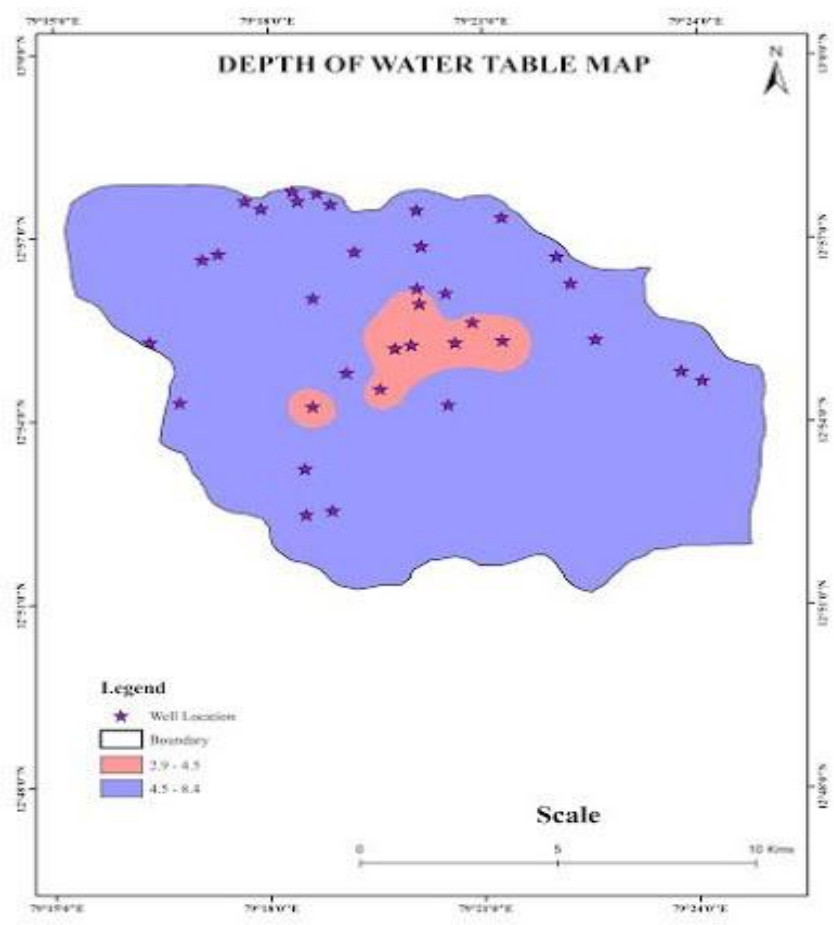

Figure 6. Depth to the water level

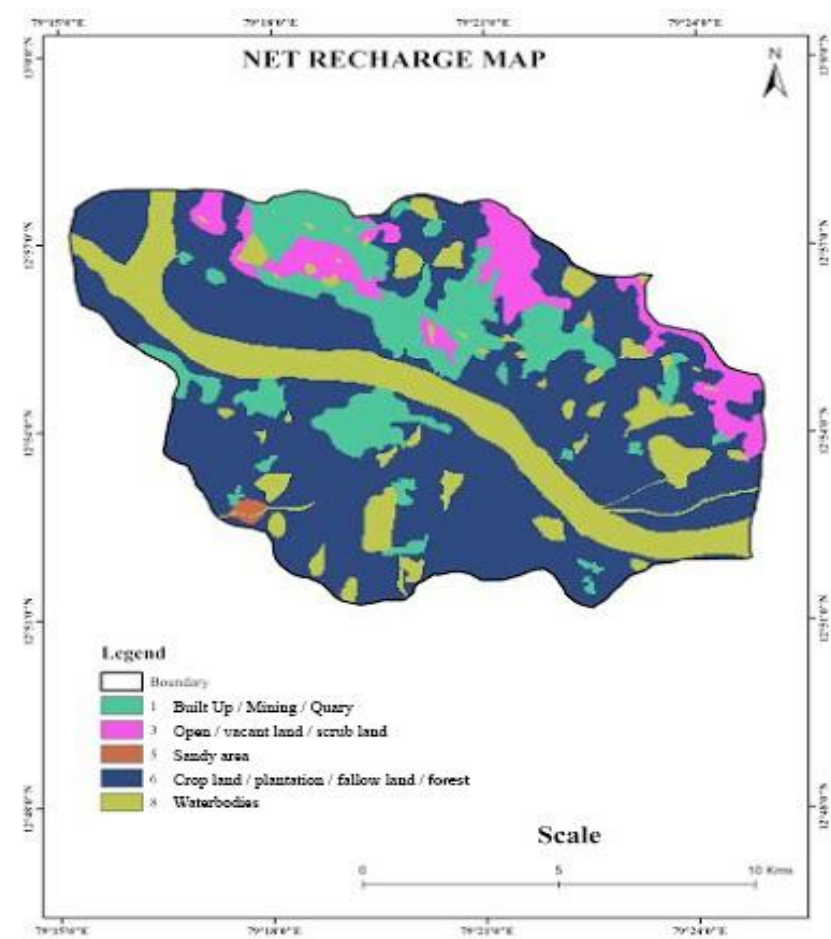

Figure 7. Net recharge map 


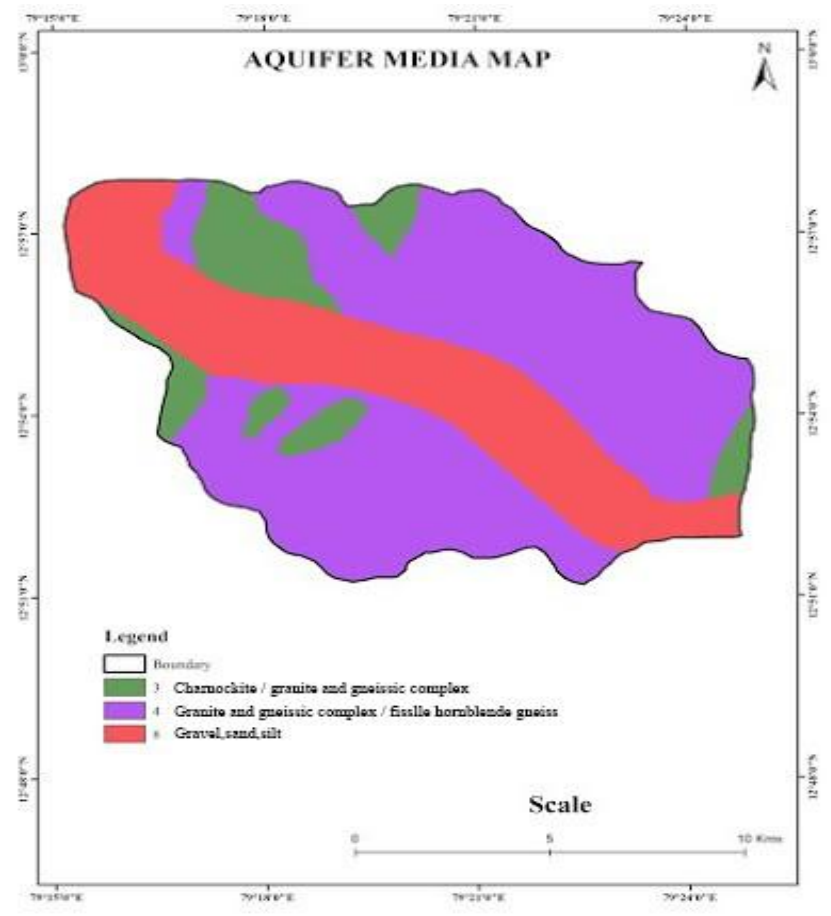

Figure 8. Aquifer media map

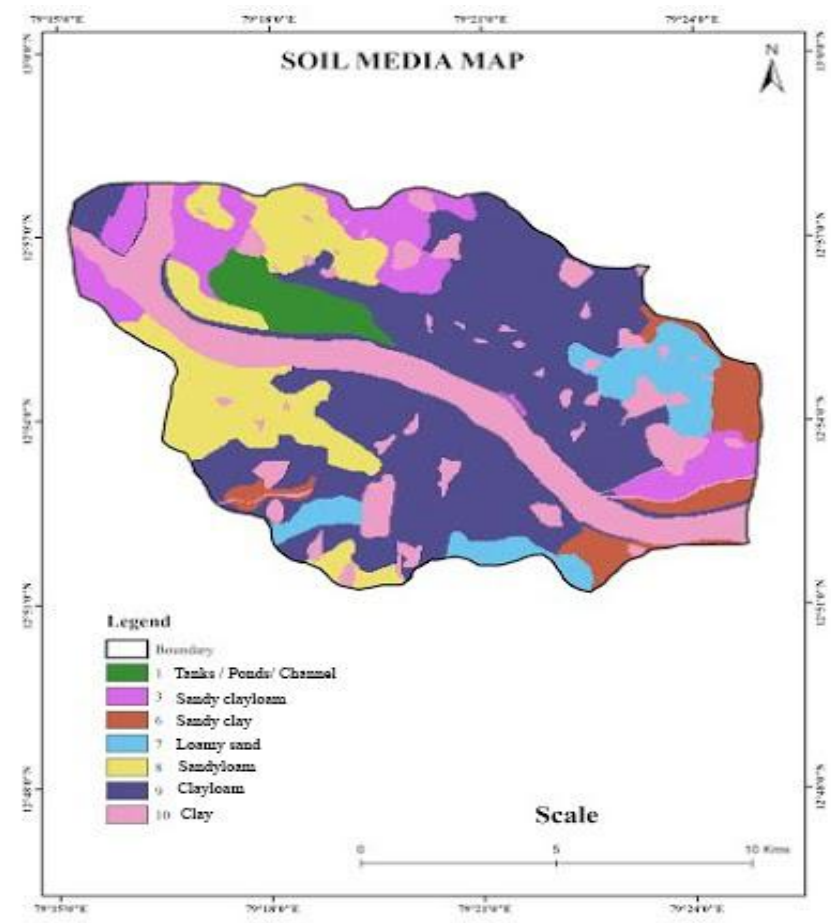

Figure 9. Soil media map

However areas with the lower slope withstand water for a longer period of time and hence allow more water to infiltrate (more vulnerable). The range of topography from 0 to greater than 18 and ratings was assigned from 10 to 1 . The topography map of the study area is given in the (Fig. 10). 


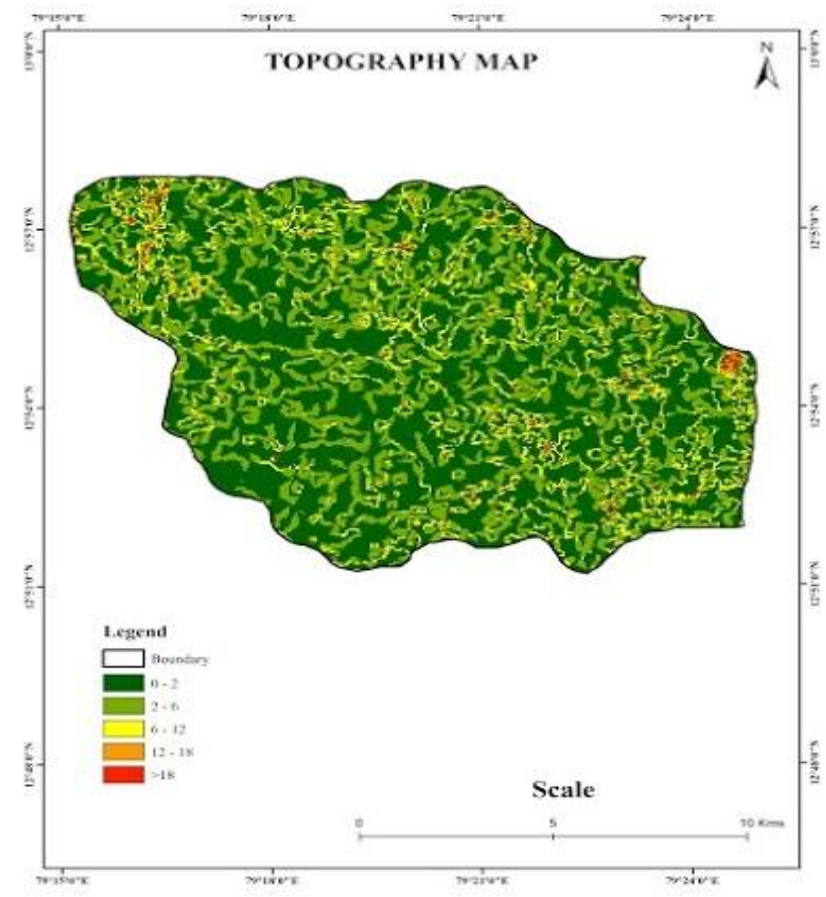

Figure 10. Topography map

Vadose zone controls the passage and attenuation of the contaminated material to the saturated zone. The study area consists of clay, sandy clay or loamy sand, channel, clay loam, sandy clay loam and sandy clay have been observed in and around Ranipet. The units having clay and loam are less vulnerable as they do not contain much of the water in the vadose zone. However, gravel, sandy and limestone areas contain groundwater and hence are vulnerable (Muhammad, 2015). They have been assigned a rating from 1 to 9 according to their properties. The map showing the vadose zone of the study area is given in the (Fig. 11).

Hence, contaminant transportation is checked by the hydraulic conductivity of the aquifer system. The hydraulic conductivity values were taken from the CGWB and the ratings and distribution have been given in the table. The map showing hydraulic conductivity is given in the (Fig. 12). All the above seven hydrogeological GIS layers have been used to generate the final vulnerability map. Using the table the rating and weights were assigned to the layers and final vulnerability range came out to be 58-699. The ranges have been given by using quantile classification method to develop the desired pattern in the map. This method distributes the range into equal groups of interval. Category ranges determined randomly will give imprecise results which are unreliable.

\section{Results and Discussions}

The DRASTIC method used to produce the map given below showing the area of very low, low, moderate, high and very high vulnerability. In the present study area the groundwater resources are well protected by the soil, aquifer media, vadose zone, and also topography. Around $70 \%$ of the area shows very high vulnerability and around $20 \%$ shows low vulnerability while less than $10 \%$ of the area is moderate vulnerability. Table 3 shows the high, moderate and low vulnerability has been assigned. In and 
around Ranipet area is highly vulnerable, while the other area such as Melvishram (Vanniyavedu) and Arcot (Mudiyor Illam) are lower and moderately vulnerable to groundwater contamination (Krogulec, 2013). The population of the four areas is increasing and so is the water demand and hence, the stress on groundwater also increases, which would further increase the groundwater exploitation. It shows that the vulnerable zones can be used as the high recharge zones and that care should be taken to prevent any leaching of contaminants on it. Measures can be taken to reduce pollution by anthropogenic activities.

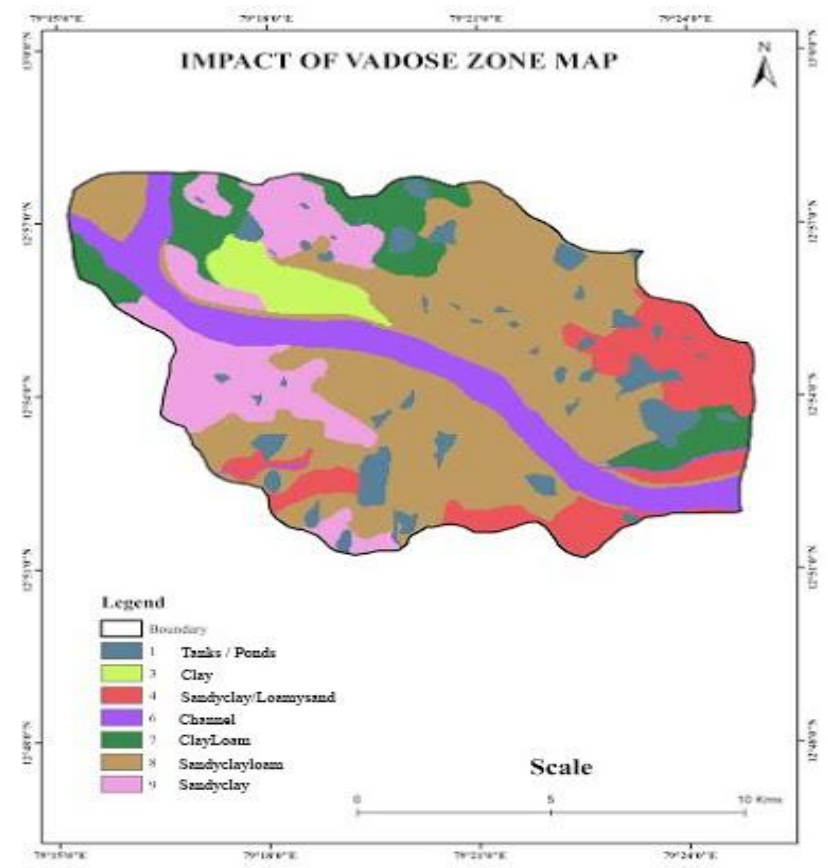

Figure 11. Impact of vadose zone map

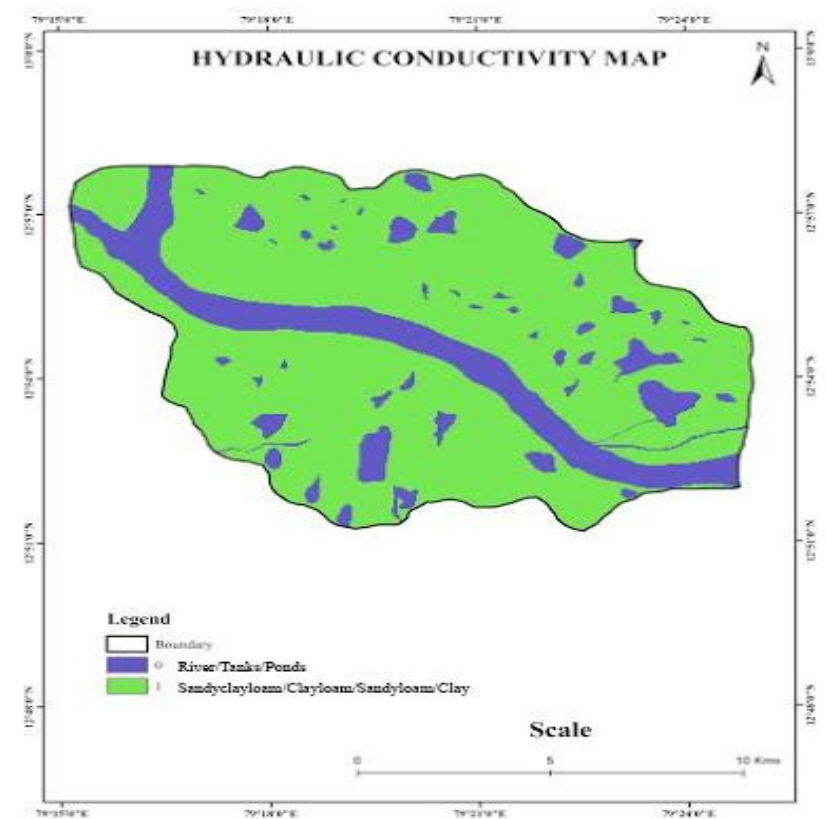

Figure 12. Hydraulic conductivity map 
Table 3. Drastic index values

\begin{tabular}{|c|c|}
\hline Range of DRASTIC index & Classification of DI \\
\hline $58-98$ & Very Low \\
\hline $98-113$ & Low \\
\hline $113-128$ & Moderate \\
\hline $128-166$ & High \\
\hline $166-699$ & Very High \\
\hline
\end{tabular}

The map obtained support the potential for contamination, especially to chromium. The DRASTIC aquifer vulnerability map is presented in (Fig. 13) shows the predominant of moderately vulnerability class (shades of green) and very high vulnerability class (blue shades). This situation is caused by small depth to water potentiated by the presence of sandstone, marl and alluvial rocks, all of which help to increase the infiltration water into the aquifer as well as increase agricultural activity and location of wastewater disposal in this region which helps to groundwater pollution.

The chromium concentration in groundwater in the study area was more than 0.05 $\mathrm{mg} / \mathrm{l}$ during November 2012 while the maximum acceptable chromium concentration in human health is less than $0.05 \mathrm{mg} / \mathrm{l}$ according to the World Health Organization it is well known that if the chromium concentration is higher than $0.05 \mathrm{mg} / \mathrm{l}$ in groundwater, it indicates anthropogenic contamination. The spatial distribution of groundwater vulnerability score was presented in (Fig. 14). Chromium concentration increases on the industrial wastewater disposal location in and around Ranipet area.

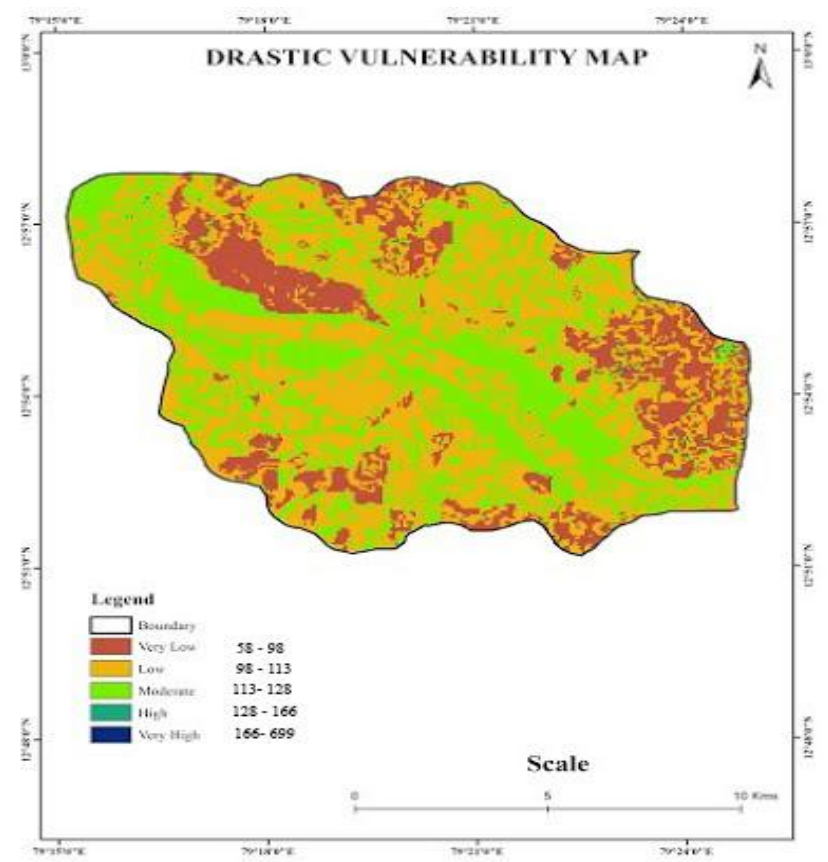

Figure 13. Drastic vulnerability map 


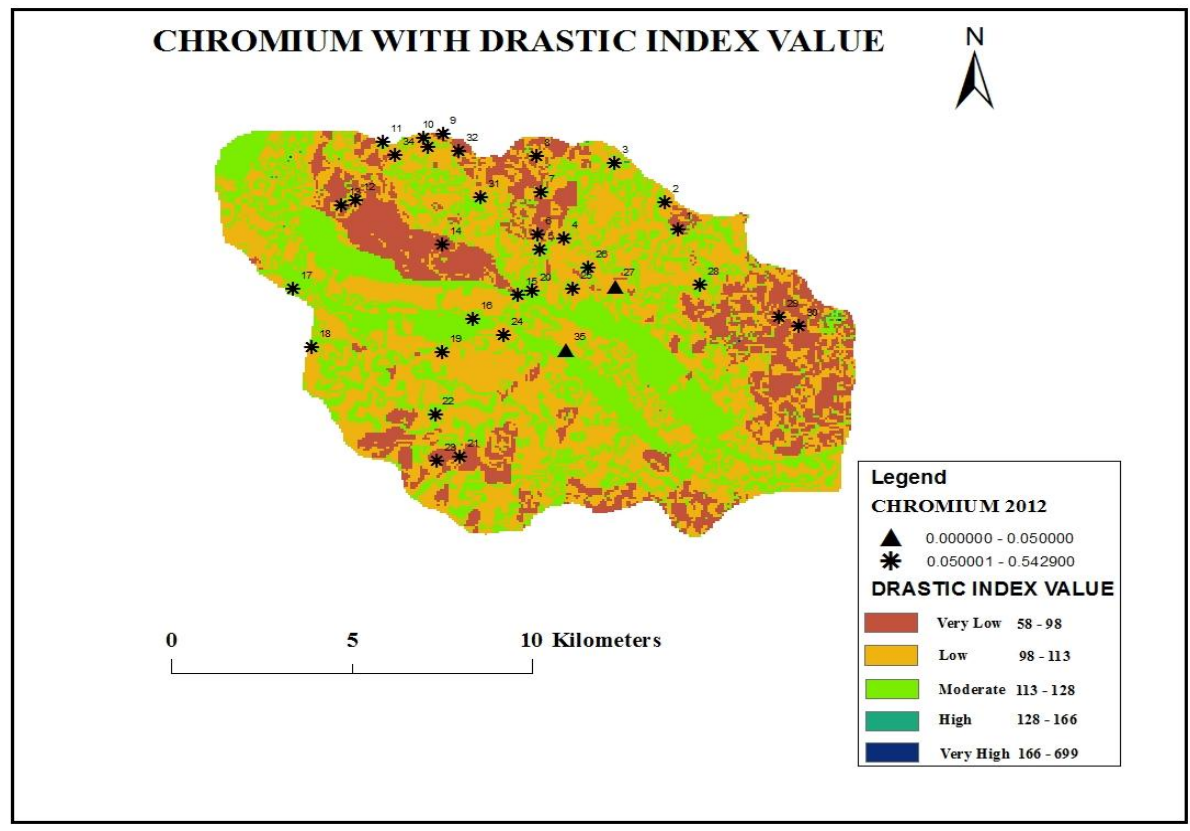

Figure 14. Spatial distribution of groundwater vulnerability scores

\section{Conclusion}

The DRASTIC vulnerability map represents the study area as classified in five categories: very low (58-98), low (98-113), moderate (113-128), high (128-166) and very high (166-699). In the study area, the depth to water was low and the hydraulic conductivity was high, which resulted in an increase in the vulnerability of the aquifer. Because the types of soil in the aquifer media, vadose zone and soil media consist of, clay, sandy clay and sandy loam, the vulnerability may be decreased. The resulting chromium concentration indicated is high in the study area and these parts are more prone to damage. Comparison of the vulnerability maps with the chromium indicated a poor relation between them. The DRASTIC method does not study the movement of groundwater. However, the movement of groundwater can displace contaminants. The reason may be due to the flow direction of the groundwater that affected the transport of pollutants The study shows that GIS can be applied to prepare various maps of different data layers and that comparing these maps is useful for groundwater management, to see how a particular area is vulnerable to groundwater pollution.

\section{REFERENCES}

[1] Al-Rawabdeh, A. M., Al-Ansari, N. A., Al-Taani, A. A., Knutsson, S. (2013): A GISbased Drastic model for assessing aquifer vulnerability in Amman-Zerqa groundwater basin. - Jordan Engineering 5: 490 -504.

[2] Bai, L., Wang, Y., Meng, F. (2012): Application of DRASTIC and extension theory in the groundwater vulnerability evaluation. - Water and Environment Journal 26(3): 381391.

[3] Environmental Systems Research Institute (ESRI) (2012): ArcGIS 10.1 Help Guides. Retrieved from: http://www.lib.uoguelph.ca/get-assistance/maps-gis-data/gisanalysis/arcgis-help-guides 
[4] Krogulec, E. (2013): Intrinsic and Specific Vulnerability of Groundwater in a River Valley - Assessment, Verification and Analysis of Uncertainty. - Journal of Earth Science \& Climatic Change 4(6): 1-12.

[5] Gupta, N. (2014): Groundwater Vulnerability Assessment using DRASTIC Method in Jabalpur District of Madhya Pradesh. - International Journal of Recent Technology and Engineering 3(3): 36-43.

[6] Mirhosseini, S. A., Zarei Mahmoodabady, H., Bemani, M. (2013): Acceptability for injury assessment of groundwater resources in plain of Ardakan-Yazd using drastic model and GIS. - Life Science Journal 10(2): 1186-1194.

[7] Mohammad, A. H., Almomani, T., Alhejoj, I. (2015): Groundwater vulnerability for the surface outcropping aquifers in Jordan. - Journal of Environmental Protection 6: 250-258.

[8] Muhammad, A. M., Zhonghua, T., Dawood, A. S., Earl, B. (2015): Evaluation of local groundwater vulnerability based on DRASTIC index method in Lahore, Pakistan. Geophysical International 54(1): 67-81.

[9] Mukherjee, N. R., Samuel, C. (2016): Assessment of the Temporal Variations of Surface Water Bodies in and around Chennai using Landsat Imagery. - Indian Journal of Science and Technology 9(18): 1-7.

[10] Neshat, A., Pradhan, B., Pirasteh, S., Shafri, H. Z. M. (2013): Estimating groundwater vulnerability to pollution using a modified DRASTIC Model in the Kermann agricultural area, Iran. - Environmental Earth Science 71: 3119-3131.

[11] Pradhan, A. N. B., Pirasteh S., Shafri, H. Z. M. (2013): Estimating groundwater vulnerability to pollution using a modified DRASTIC Model in the Kermann agricultural area, Iran. - Environmental Earth Science 71(7): 3119-31.

[12] Tirkey, P., Gorai, A. K., Iqbal, J. (2013), AHP-GIS based DRASTIC model for groundwater vulnerability to pollution assessment: A case study of Hazaribag district, Jharkhand, India. - International Journal of Environmental Protection 2: 20-31.

[13] Wang, J., He, J., Chen, H. (2012): Assessment of groundwater contamination risk using hazard quantification, a modified DRASTIC model and groundwater value, Beijing Plain, China. - Science of the Total Environment 432: 216-226. 